\title{
Mineral Fertilization Increases Litterfall in Degraded Soils by Arenization
}

\author{
Huan Pablo de Souza \\ Dr. Forest Engineering - UFSM, Brazil \\ Angélica Costa Malheiros, Dione Richer Momolli \\ Forest Engineer - UFSM, Brazil \\ Aline Aparecida Ludvichak, Claudiney Couto Guimarães \\ Dr. Forest Engineering - UFSM, Brazil \\ José Mateus Wisniewski Gonsalves \\ Futuragene Brasil Tecnologia, Brazil \\ Mauro Valdir Schumacher \\ Prof. Dr. Forest Engineering - UFSM.
}

Received: July 12, 2021 Accepted: August 3, $2021 \quad$ Published: August 8, 2021

doi:10.5296/jas.v9i3.18853 URL: https://doi.org/10.5296/jas.v9i3.18853

\begin{abstract}
Young stands on sandy soils with low natural fertility are more dependent on chemical fertilization. The litterfall becomes the most important route for biogeochemical cycling in an ecosystem. Therefore, the aim of the study was to quantify the annual litterfall, evaluate the seasonality of deposition and verify the litterfall response under different amounts of fertilizers in a young eucalyptus stand implanted in soil degraded by arenization in southern Brazil. Litterfall was evaluated using litter traps with an area of $0.5 \mathrm{~m}^{2}$. Fortnightly, over a year, collections and quantification of dry mass were performed. Each of the 5 fertilizer treatments received increasing amounts of nutrients. The litterfall had seasonal pattern, with larger quantities for the spring season, with statistical difference at a level of 5\% probability
\end{abstract}


of error from other seasons evaluated, marked by the increase in temperatures. The amount of litterfall, in descending order, followed the amount of nutrients applied in the treatments: $\mathrm{T} 5>\mathrm{T} 3>\mathrm{T} 4>\mathrm{T} 2>\mathrm{T} 1$. The annual litterfall ranged from 518 to $1326 \mathrm{~kg} \mathrm{ha}^{-1}$ of the treatment that received natural phosphate (T1) and triple superphosphate (T5), respectively. This variation represents an increase of $156 \%$. The increase in litterfall is associated with the amount of fertilizers.

Keywords: nutrient cycling, sustainability, Eucalyptus urophylla, arenization, forestry

\section{Introduction}

The forestry sector has been gaining space in the Brazilian Economy, by growing $12.6 \%$ in 2019, much higher than the $1.1 \%$ national average increase of Gross Domestic Product (GDP). Moreover, it achieved more significant increases than farming/agriculture and livestock sector, services sector, and industry of all types, which grew by about $0.1 \%, 1.3 \%$, and $0.6 \%$, respectively. The evolution of the segment contributes to $1.2 \%$ of the national GDP, and $6.9 \%$ of the industrial GDP (IBÁ, 2020).

This economic activity highlights the importance of maintaining environmental resources, through the establishment of degraded areas recovery programs, and the conservation of Permanent Preservation Areas (PPA), Legal Reserves (LR) and Private Natural Heritage Reserves (PNHR). Besides environmental gains, the sector contributed significantly to the Human Development Index (HDI): according to surveys conducted from 2000 to 2011, municipalities with commercial forest plantations grew 56\%, more than the average $(47 \%)$ for this indicator in the country (IBÁ, 2020).

Forestry occupies the most diverse types of soils, which present different available and total levels of nutrients, leading to variations in forest essences yield (BARROS; COMEFORD, 2002). The total area of forests in the world corresponds to 4.06 billion hectares, with $45 \%$ concentrated in the tropic's region, followed by $27 \%$ in boreal forests, $16 \%$ in temperate forests, and $11 \%$ in subtropical forests (FAO, 2020).

In the western region of Rio Grande do Sul state, there are sandstone cores that developed due to the composition of the rocky base, the relief and water regime of the site, and worsened by anthropic activities. It is common to observe the formation of mixed prairie vegetation under the sands, which is constantly degraded by the action of water and wind erosion (SUERTEGARAY, 1995; ROVEDDER \& ELTZ, 2008).

Considering that soil is a slowly renewable natural resource, emergency techniques to contain wind erosion and stabilize soil surface are carried out in these regions. The use of fast-growing tree species for instance, makes it possible to start the process of recovery of these degraded areas, rebalancing nutrient cycling and incorporating organic matter into the soil (ROVEDDER et. al, 2008).

The genus Eucalyptus can be used in the recovery process of degraded areas, as it includes species adapted to dystrophic soils, with little response to acidity and tolerance to high concentrations of $\mathrm{Al}$ and $\mathrm{Mn}$. Eucalyptus urophylla is particularly adapted to different sites, 
presents rapid growth and drought resistance, in addition to high potential for rooting and sprouting of strains (GONÇALVES et al., 2004; FONSECA et al, 2010).

Therefore, fertilization is one of the factors that optimize and accelerate the establishment of silviculture in sandy soils (BARROS \& NOVAIS 1995). The effects of fertilization are even more evident in low-fertility soils with trees up to 24 months of age, when the canopy closes and the priority for allocation of photo-assimilates switches from leaf area expansion to trunk expansion (LACLAU et al, 2010). Chemical fertilization may be responsible for the increase in litter production. O'Connell and Mendham (2004), studying the Impact of Nitrogen (N) and Phosphorus (P) fertilizer application on nutrient cycling in Eucalyptus marginata forests of south western Australia, concluded that litterfall was significantly increased by $\mathrm{N}$ application (30\% relative to controls) in the first 2 years after treatment and by $\mathrm{P}$ application in the second year.

The objective of the study was to evaluate the influence of the different amounts of chemical fertilizers applied in the production of litter in a stand of Eucalyptus urophylla located in a sandstone area.

\section{Method}

\subsection{Characterization of the Experiment}

The experiment was set in the Pampa biome, located at Arroio Puitã watershed, in the

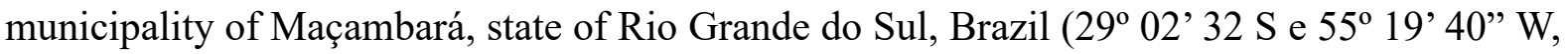
191 meters above sea level). The smooth relief in this region was geologically formed by basaltic spills, sandstone outcrops and large alluvium in the river plains. It is covered predominantly by grassland vegetation, with sporadic capons' formation in the middle of the fields, and broadleaf species. On the riverbank, gallery forests with shrub aspect are present (IFCRS, 2002).

According to Köppen climate classification, the region of Maçambará is classified as Subtropical Cfa, with hot summers and rains more frequent in autumn and winter. The average annual precipitation is $1628 \mathrm{~mm}$, the average annual temperature is $20.7{ }^{\circ} \mathrm{C}$ and the average of the hottest month is $26.3{ }^{\circ} \mathrm{C}$. In winter, negative temperatures and frosts can occur combined with Southwest wind, while Northeast wind predominates in spring (ALVARES et al., 2014). Figure 1 shows meteorological data series for the period from April 2016 to march 2017, obtained from the weather station located in Maçambará - RS - Brazil at $168 \mathrm{~m}$ altitude, latitude -29.00 and longitude -56.00 . 


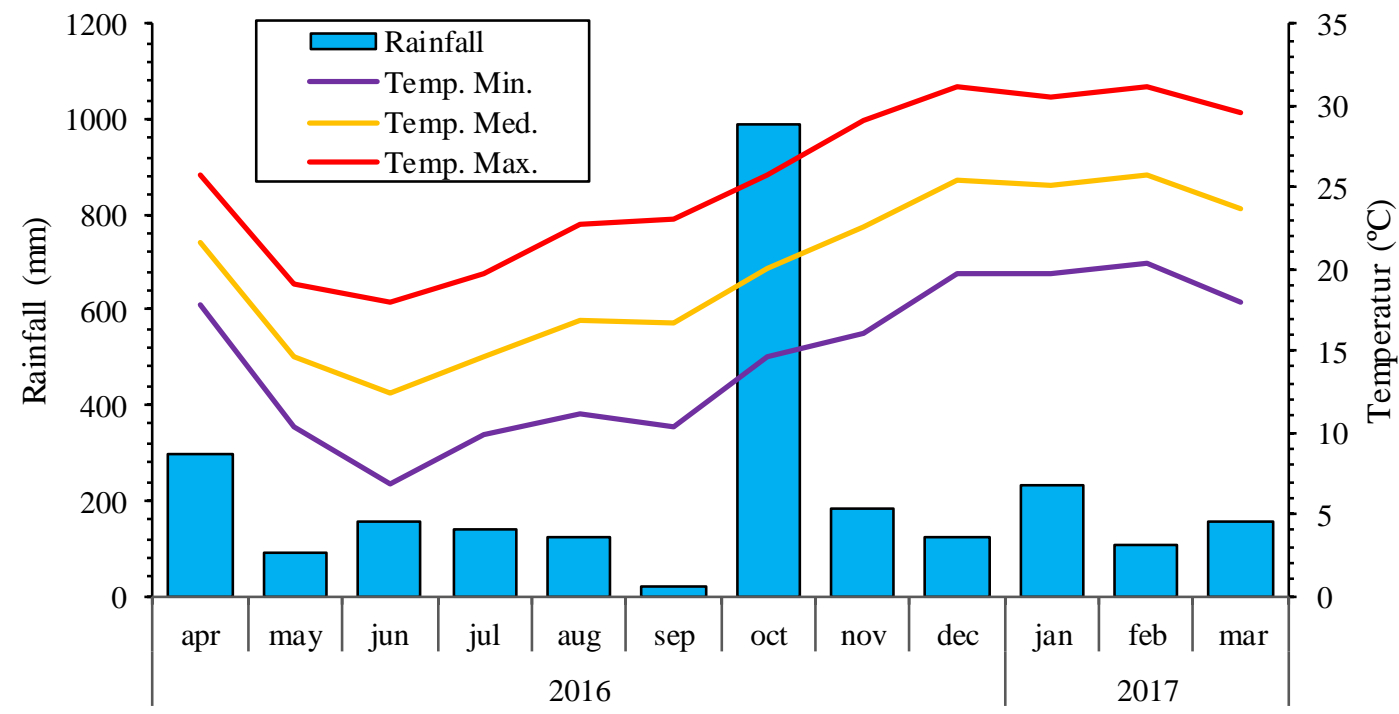

Figure 1. Meteorological data for the municipality of Maçambará - Brazil, during the study period

The soil of the experimental area is classified as Entisols (Quartzipsamments), predominantly sandy texture with an average percentage of 85.2, 3.0, 2.3 and 9.5\% for coarse sand, fine sand, silt and clay respectively. Regarding chemical attributes, the average organic matter content up to $1 \mathrm{~m}$ deep was very low, $0.24 \%$. Base saturation (V) $5.0 \%$ indicates that it is a dystrophic soil with low natural fertility (SBCS-CQFS, 2016). The soil profile presented homogeneity of the attributes analyzed between the different depths and did not present any active biological activity in the soil, nor was to the presence of roots (live or dead). Table 1 presents the physical and chemical attributes of the soil.

Table 1. Physical-chemical attributes of the soil in the experimental site with Eucalyptus urophylla stand in the degraded sois by arenization.

\begin{tabular}{|c|c|c|c|c|c|c|c|c|c|c|c|}
\hline \multirow{3}{*}{ Attribute } & \multirow{3}{*}{ Unit } & \multicolumn{10}{|c|}{ Depth (cm) } \\
\hline & & 0 & 20 & 40 & 60 & 80 & 100 & 120 & 140 & 160 & 180 \\
\hline & & 20 & 40 & 60 & 80 & 100 & 120 & 140 & 160 & 180 & 200 \\
\hline SD & $\mathrm{g} \mathrm{cm}^{-3}$ & 2.1 & 2.3 & 1.9 & 1.8 & 1.7 & 1.8 & 1.9 & 1.7 & 1.6 & 1.6 \\
\hline $\mathrm{CS}$ & \multirow{5}{*}{$\%$} & 88.0 & 88.3 & 86.0 & 81.3 & 82.3 & 84.0 & 77.6 & 81.0 & 84.0 & 82.0 \\
\hline FS & & 3.0 & 3.5 & 3.0 & 4.0 & 1.6 & 2.7 & 4.3 & 5.4 & 3.3 & 3.4 \\
\hline Silt & & 1.0 & 1.6 & 1.0 & 3.0 & 4.7 & 2.6 & 6.0 & 2.3 & 1.4 & 3.3 \\
\hline Clay & & 8.0 & 6.6 & 10.0 & 11.6 & 11.3 & 10.6 & 12.0 & 11.3 & 11.3 & 11.3 \\
\hline O.M. & & 0.2 & 0.2 & 0.3 & 0.3 & 0.2 & 0.2 & 0.2 & 0.2 & 0.1 & 0.1 \\
\hline $\mathrm{pH}$ & $1: 2,5 \mathrm{H}_{2} \mathrm{O}$ & 4.8 & 4.7 & 4.6 & 4.6 & 4.6 & 4.6 & 4.6 & 4.7 & 4.7 & 4.6 \\
\hline $\mathrm{Al}$ & \multirow{3}{*}{$\mathrm{cmol}_{\mathrm{c}} \mathrm{dm}^{-3}$} & 0.7 & 0.6 & 0.8 & 0.8 & 0.9 & 0.9 & 0.9 & 0.8 & 0.9 & 1.0 \\
\hline $\mathrm{Ca}$ & & 0.2 & 0.1 & 0.1 & $<0.1$ & 0.2 & 0.2 & 0.1 & $<0.1$ & 0.1 & $<0.1$ \\
\hline $\mathrm{Mg}$ & & 0.1 & $<0.1$ & $<0.1$ & $<0.1$ & 0.1 & $<0.1$ & $<0.1$ & $<0.1$ & $<0.1$ & $<0.1$ \\
\hline $\mathrm{P}^{\mathrm{a}}$ & \multirow{2}{*}{$\mathrm{mg} \mathrm{dm}^{-3}$} & 4.6 & 3.4 & 2.3 & 2.9 & 3.5 & 4.3 & 5.0 & 6.9 & 7.3 & 6.9 \\
\hline $\mathrm{K}^{\mathrm{a}}$ & & 13.3 & 12.7 & 14.8 & 13.8 & 14.1 & 14.0 & 13.3 & 14.5 & 13.5 & 13.3 \\
\hline CECef & \multirow{2}{*}{$\mathrm{cmol}_{\mathrm{c}} \mathrm{dm}^{-3}$} & 0.9 & 0.7 & 0.9 & 0.9 & 1.1 & 1.1 & 1.0 & 1.0 & 0.9 & 1.1 \\
\hline $\mathrm{CECpH}_{7}$ & & 2.6 & 2.9 & 3.6 & 3.7 & 3.8 & 3.9 & 3.8 & 3.7 & 3.8 & 3.7 \\
\hline $\mathrm{V}$ & \multirow{2}{*}{$\%$} & 7.7 & 4.6 & 4.6 & 3.2 & 4.9 & 5.1 & 3.7 & 2.6 & 2.9 & 2.5 \\
\hline M & & 77.2 & 82.1 & 81.7 & 87.0 & 82.9 & 82.3 & 86.1 & 90.4 & 88.6 & 91.3 \\
\hline $\mathrm{S}$ & \multirow{4}{*}{$\mathrm{mg} \mathrm{dm}^{-3}$} & 3.9 & 10.1 & 13.9 & 15.6 & 15.9 & 14.4 & 14.6 & 7.0 & 8.9 & 7.7 \\
\hline B & & 0.3 & 0.3 & 0.4 & 0.4 & 0.3 & 0.3 & 0.2 & 0.2 & 0.2 & 0.3 \\
\hline $\mathrm{Cu}$ & & 0.4 & 0.4 & 0.5 & 0.5 & 0.6 & 0.5 & 0.6 & 0.5 & 0.5 & 0.4 \\
\hline $\mathrm{Zn}$ & & 0.2 & 0.1 & 0.1 & 0.1 & 0.1 & 0.1 & 0.2 & 0.1 & 0.1 & 0.1 \\
\hline
\end{tabular}


Where: $S D=$ soil density; $C S=$ coarse sand; $F S=$ fine sand; $O . M=$ organic matter; ${ }^{a}$ Extraction method Melich I. CECef = cation exchange capacity effective; $C E C e f=$ cation exchange capacity $p H$ 7.0; $V=$ base saturation; $m=$ aluminum saturation

The experimental area was prepared in May 2015 by sub-soiling $30 \mathrm{~cm}$ deep and applying granulated ant killer. Planting was carried out manually, using Eucalyptus urophylla clonal seedlings at $3.0 \mathrm{~m} \times 2.0 \mathrm{~m}$ spacing. The experiment was set in a completely randomized design (CRD) with five treatments, containing three replicates each. The treatments were called T1, T2, T3, T4 and T5, measuring $60 \mathrm{~m}$ x $30 \mathrm{~m}$, with 300 trees each.

The treatments received different sources and doses of fertilization. Table 2 shows the total amount applied for each element. Phosphorus dosages were used in the base fertilization. Treatments 2, 3, 4 and 5 received increasing doses of triple superphosphate, varying between $112.5-225 \mathrm{~kg} \mathrm{ha}^{-1}$. T1 received natural phosphate in the base fertilization. This application was performed in a single dose. All fertilizations were carried out manually inside pits, incorporating the fertilizer at a depth of 5 to $10 \mathrm{~cm}$ and a distance of $20 \mathrm{~cm}$ from the seedlings.

Table 2. Total amount of nutrients applied in each treatment

\begin{tabular}{cccccc}
\hline \multirow{2}{*}{ Nutrient } & \multicolumn{5}{c}{ Total of nutrients $\left(\mathrm{kg} \mathrm{ha}^{-1}\right)$} \\
\cline { 2 - 6 } & $\mathrm{T} 1$ & $\mathrm{~T} 2$ & $\mathrm{~T} 3$ & $\mathrm{~T} 4$ & $\mathrm{~T}$ \\
\hline $\mathrm{N}$ & 54.4 & 94.0 & 102.4 & 84.0 & 156.4 \\
$\mathrm{P}_{2} \mathrm{O}_{5}$ & 30.0 & 96.0 & 72.0 & 84.0 & 153.0 \\
$\mathrm{~K}_{2} \mathrm{O}$ & 45.6 & 80.4 & 86.4 & 99.6 & 169.8 \\
$\mathrm{ST}^{*}$ & - & 112.5 & 149.8 & 187.2 & 225.0 \\
$\mathrm{FN}^{* *}$ & 120.6 & - & - & - & - \\
$\mathrm{Ca}$ & - & 12.8 & 16.3 & 19.9 & 24.9 \\
$\mathrm{~S}$ & - & 10.3 & 13.1 & 16.0 & 20.0 \\
$\mathrm{~B}$ & - & 3.2 & 4.1 & 5.0 & 6.3 \\
$\mathrm{Cu}$ & - & 1.4 & 1.8 & 2.2 & 2.8 \\
$\mathrm{Mn}$ & - & 3.6 & 4.6 & 5.6 & 7.0 \\
$\mathrm{Mo}$ & - & 0.2 & 0.2 & 0.3 & 0.4 \\
$\mathrm{Zn}$ & - & 16.2 & 20.7 & 25.2 & 31.5 \\
\hline
\end{tabular}

Note: ST* - Triple superphosphate; FN** - Natural phosphate.

\subsection{Litterfall Sampling}

To estimate litterfall, in each of the plots of the different treatments, litter traps were systematically distributed, allocated in different positions: one in the planting line, another in the planting row, and the third diagonally to the planting line, between four trees. The litter traps were made with eucalyptus wood, with $0.49 \mathrm{~m}^{2},(0.70 \mathrm{~m} \times 0.70 \mathrm{~m})$ of collection area, with nylon mesh bottom $(1 \mathrm{~mm})$, installed at $30 \mathrm{~cm}$ height from ground level. Collects were carried out monthly. Figure 2 shows the appearance of the litter trap in the study area. 

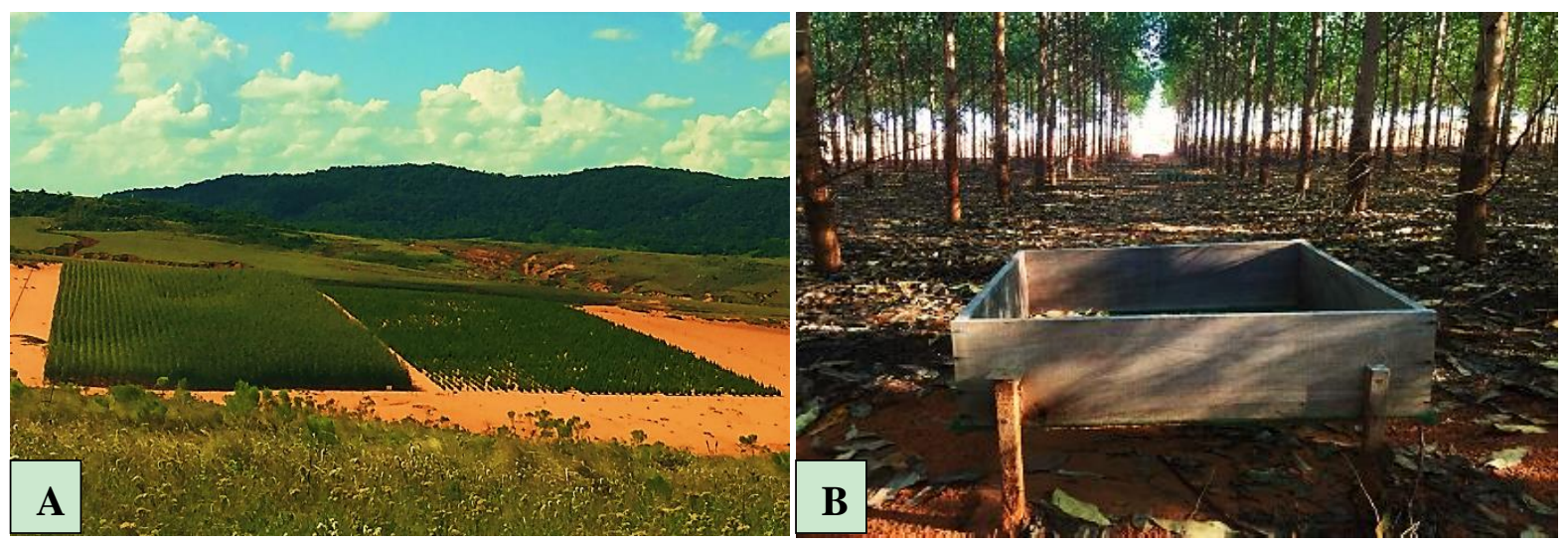

Figure 2. Figure (A) shows the experimental study in degraded soil and Figure (B) the litter trap in a Eucalyptus urophylla stand

From each monthly collection, the average amount of litter deposition was estimated. The annual litter production estimate $\left(\mathrm{OS}_{\mathrm{j}} \mathrm{ha}^{-1} \mathrm{year}^{-1}\right)$ was based on the formula suggested by Lopes, Domingos and Struffaldide Vuono (2002), adapted to this study:

$$
P S_{j}=\left(\frac{10.000}{A C}\right) \sum_{i j} P M S_{i j},\left[\begin{array}{c}
i=1,2, \ldots, 12 \text { months } \\
j=1,2,3,4 \text { years }
\end{array}\right]
$$

The results were statistically analysed through the Sisvar software, using Tukey's test (5\% probability of error) and considering the completely randomized design. All treatments ware analysed through each collected month, composed by tree collection spots (at planting line, planting row and at diagonally position) corresponding to one replicate each.

\subsection{Data Analysis}

Analysis of variance (ANOVA) was performed through the Sisvar software to verify if their significant statistical differences: between treatments and between amount seasonal litterfall. When the ANOVA was significant, a means test (Tukey) was performed at 5\% probability of error to know which variables differed from each other.

Regression equations were adjusted for litterfall as a function of the amount of mineral fertilization using IBM SPSS 20.0. The distribution of the regression residues was analyzed in order to validate the homogeneity of variance. The percentage of residues were presented in graphic form as a function of the variable analyzed.

\section{Results}

The production of litter had seasonal pattern, with larger quantities for the spring season, which differed significantly from other seasons evaluated. The annual litterfall varied from 518 to $1326 \mathrm{~kg} \mathrm{ha}^{-1}$ of the treatment that received less for a greater quantity of fertilizers (T1 T5) respectively. This variation represents an increase of $158 \%$. The statistical analysis of litter production in the different chemical fertilization treatments can be seen in Table 3 . 
Table 3. Litter deposition in different seasons and treatments in a stand of Eucalyptus urophylla, in a sandy soil in the municipality of Maçambará - Brazil

\begin{tabular}{|c|c|c|c|c|c|c|}
\hline \multirow{2}{*}{ Seasons } & \multicolumn{5}{|c|}{ Litterfall $\left(\mathrm{kg} \mathrm{ha}^{-1}\right)$} & \multirow{2}{*}{ Mean } \\
\hline & $\mathrm{T} 1$ & $\mathrm{~T} 2$ & $\mathrm{~T} 3$ & $\mathrm{~T} 4$ & $\mathrm{~T} 5$ & \\
\hline Autumn & $25.01 A a$ & $38.73 \mathrm{Ba}$ & $30.34 \mathrm{Ba}$ & $56.50 \mathrm{Ba}$ & $50.41 B a$ & $40.20 B$ \\
\hline Winter & $133.83 \mathrm{Aab}$ & 179.21 $A B a b$ & $168.20 \mathrm{ABab}$ & $308.74 A a$ & $317.98 \mathrm{ABa}$ & $221.59 A B$ \\
\hline Spring & $251.56 A b$ & $533.75 A a b$ & $554.76 \mathrm{Aab}$ & $538.32 \mathrm{Aab}$ & $691.47 A a$ & $513.97 A$ \\
\hline Summer & $107.35 A b$ & $215.96 \mathrm{ABa}$ & $302.37 A a$ & $174.74 \mathrm{ABa}$ & $266.63 A B a$ & $213.41 A B$ \\
\hline Total Year & $517.76 b$ & $967.64 a b$ & $1055.67 a b$ & $1078.30 a b$ & $1326.49 a$ & 989.17 \\
\hline Monthly Mean & $43.14 b$ & $80.64 a b$ & $87.97 a b$ & $89.85 a b$ & $110.54 a$ & 82.42 \\
\hline
\end{tabular}

Where: uppercase letters in the vertical indicate significant differences between the seasons, lowercase letters in the horizontal indicate significant differences between treatments.

There was no significant difference in litter deposition between treatments in autumn season. On the other hand, during summer the treatments T1 and T3 showed lower and higher deposition, respectively, differing significantly from the others, which followed the sequence $\mathrm{T} 5>\mathrm{T} 4>\mathrm{T} 3>\mathrm{T} 2>\mathrm{T} 1$. During spring, only treatment $\mathrm{T} 1$ differed significantly, while the others followed the sequence T5 $>$ T3 $>$ T4 $>$ T2 $>$ T1. During winter, treatments T1 and T5 showed lower and higher litter deposition, respectively.

Treatments T1 showed the same pattern of litter deposition for all seasons, not varying significantly during the year studied. However, for treatments T2, T3, T4 and T5, the lowest litter deposition occurred in autumn, while the largest occurred during spring, when the leaves were renewed and flower buds were developed. Treatments T2 and T3 followed the same deposition sequence: spring > summer > winter > autumm, while treatments 1,4 and 5 had the following deposition order: spring $>$ winter $>$ summer $>$ autumm.

There was a significant difference in deposition according to the season and fertilization; however, there was no significant interaction between the two factors, that is, the seasons did not influence the effect of fertilization. Although deposition was generally lower in the autumn and higher in the spring, the values did not follow a pattern sufficiently significant to show interaction, with discrepant values appearing in some treatments.

Despite this, the average deposition in the spring considering all treatments $\left(514 \mathrm{~kg} \mathrm{ha}^{-1}\right)$ was significantly higher than in the other seasons, and in the autumn (40 kg ha-1) it was significantly lower. Still, the monthly average deposition of treatment 5 was $\left(111 \mathrm{~kg} \mathrm{ha}^{-1}\right)$ was significantly higher than the others, while in treatment $1\left(43 \mathrm{~kg} \mathrm{ha}^{-1}\right)$ was significantly lower.

According to Figure 3, there appears to be a high level of similarity in the deposition of litter between the different treatments, where they all showed the same deposition pattern, peaking in the month of November. The tendency to reduce the deposited volume was also observed for all treatments. In the first months of collection, it was only possible to identify the leaf fraction in the collectors, with the branches and miscellaneous fractions being insignificant. 


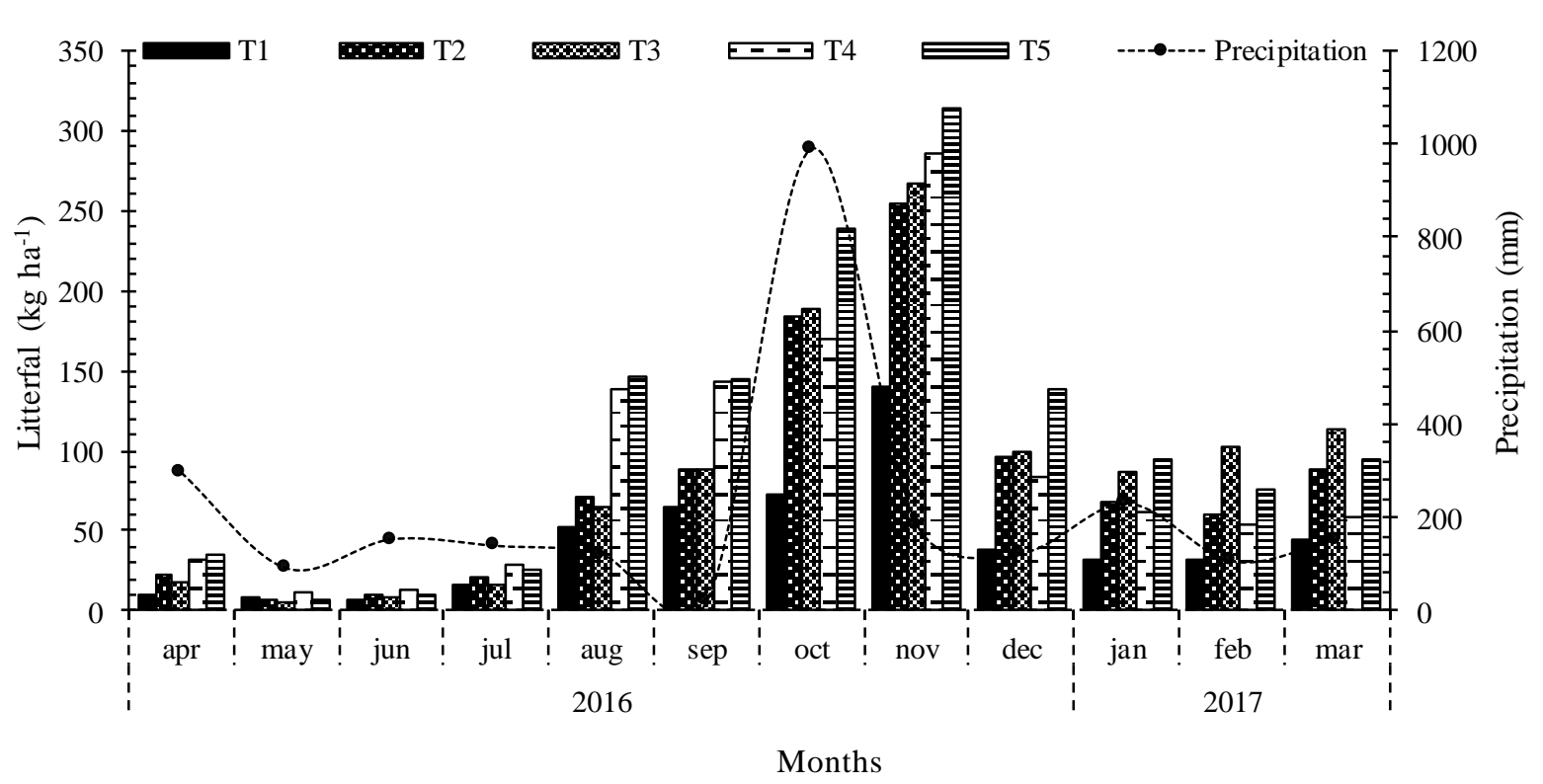

Figure 3. Litter deposition and rainfall throughout the months in the experiment with Eucalyptus urophylla, in degraded soils by arenization

The highest amount of litter deposited in a month was observed in November 2016, for all treatments, where $\mathrm{T} 5$ obtained the highest deposition of $314.51 \mathrm{~kg} \mathrm{ha}^{-1}$. The lowest deposition for that month was observed in T1, with $140.66 \mathrm{~kg} \mathrm{ha}^{-1}$. The lowest amount deposited for all treatments was observed in May 2016, where the highest accumulation occurred in T4 with $11.12 \mathrm{~kg} \mathrm{ha}^{-1}$, whereas the lowest deposition in that month was observed for T3, with only $4.49 \mathrm{~kg} \mathrm{ha}^{-1}$.

The study region comprises a sandstone core that continues to expand. The causes for it are due to the type of geological formation to the inadequate use of the soil by the anthropic action, highlighting grazing as a form of economic activity prevalent in the past. In order to chemically correct the soil, different treatments with fertilizer quantities were applied. Figure 4 shows the amount of litter produced as a function of the amount of fertilizers applied to the soil. In general, there were excellent polynomial adjustments in the amount of litter produced as a function of the amount of fertilizers. The coefficients were 0.99, 0.90, 0.99 and 0,97 for $\mathrm{N}, \mathrm{P}_{2} \mathrm{O}_{5}, \mathrm{~K}_{2} \mathrm{O}$ and triple superphosphate respectively, that is, the greater amount of fertilizers increased the amount of litter produced (Figure 4). 


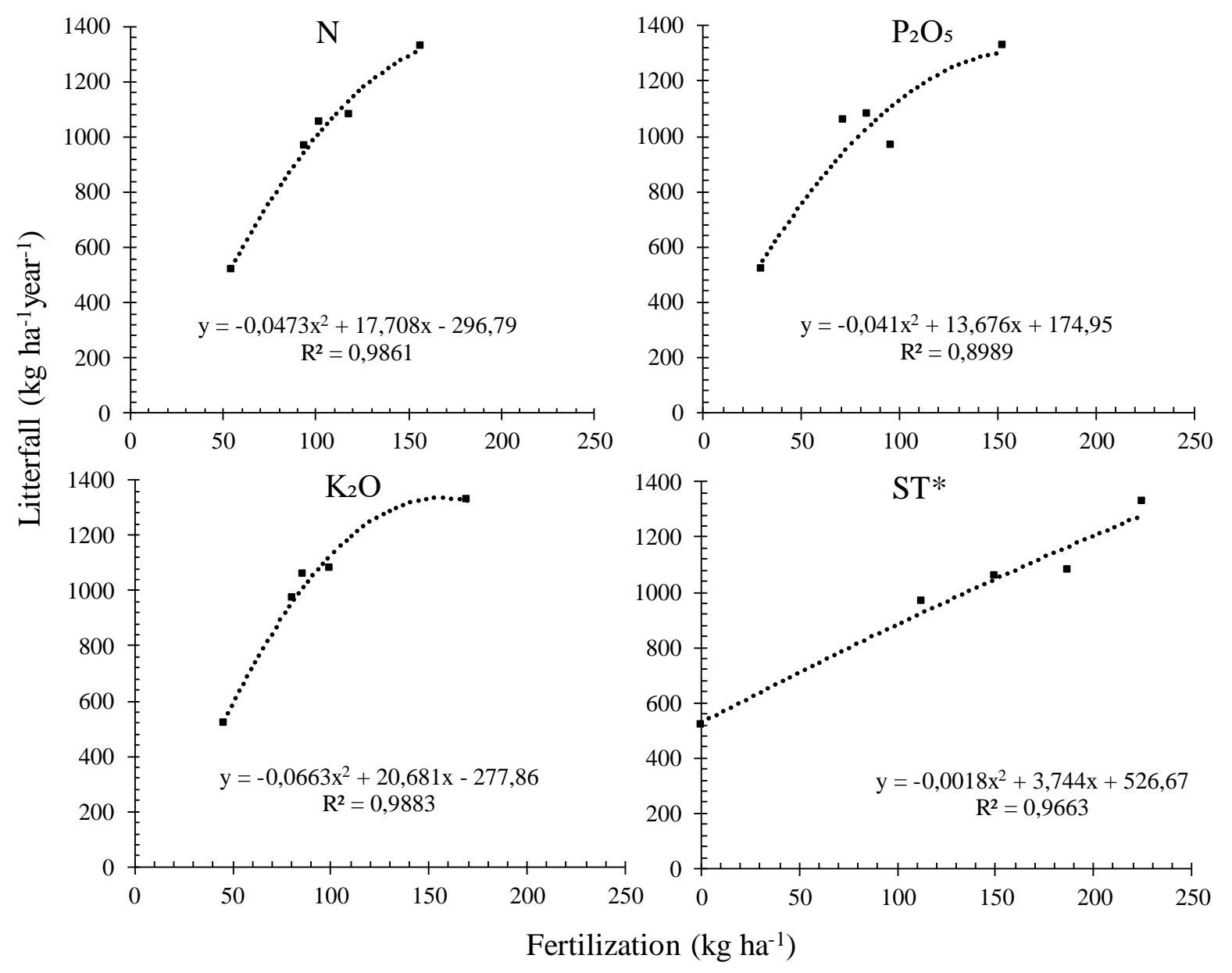

Figure 4. Regression analysis of litterfall as a function of the amount of mineral fertilizer

The adjustments of the polynomial regression analysis showed the best results when compared to linear, exponential and logarithmic regressions. In addition to the excellent $\mathrm{R}^{2}$ coefficients, the graphical distribution analysis of the residuals reinforces the adjustments. Figure 5 shows the distributions of the residuals. The graphical analysis validates the homogeneity of variance. It is observed that there is no tendency to over or underestimate litterfall due to different amounts of mineral fertilizers. 


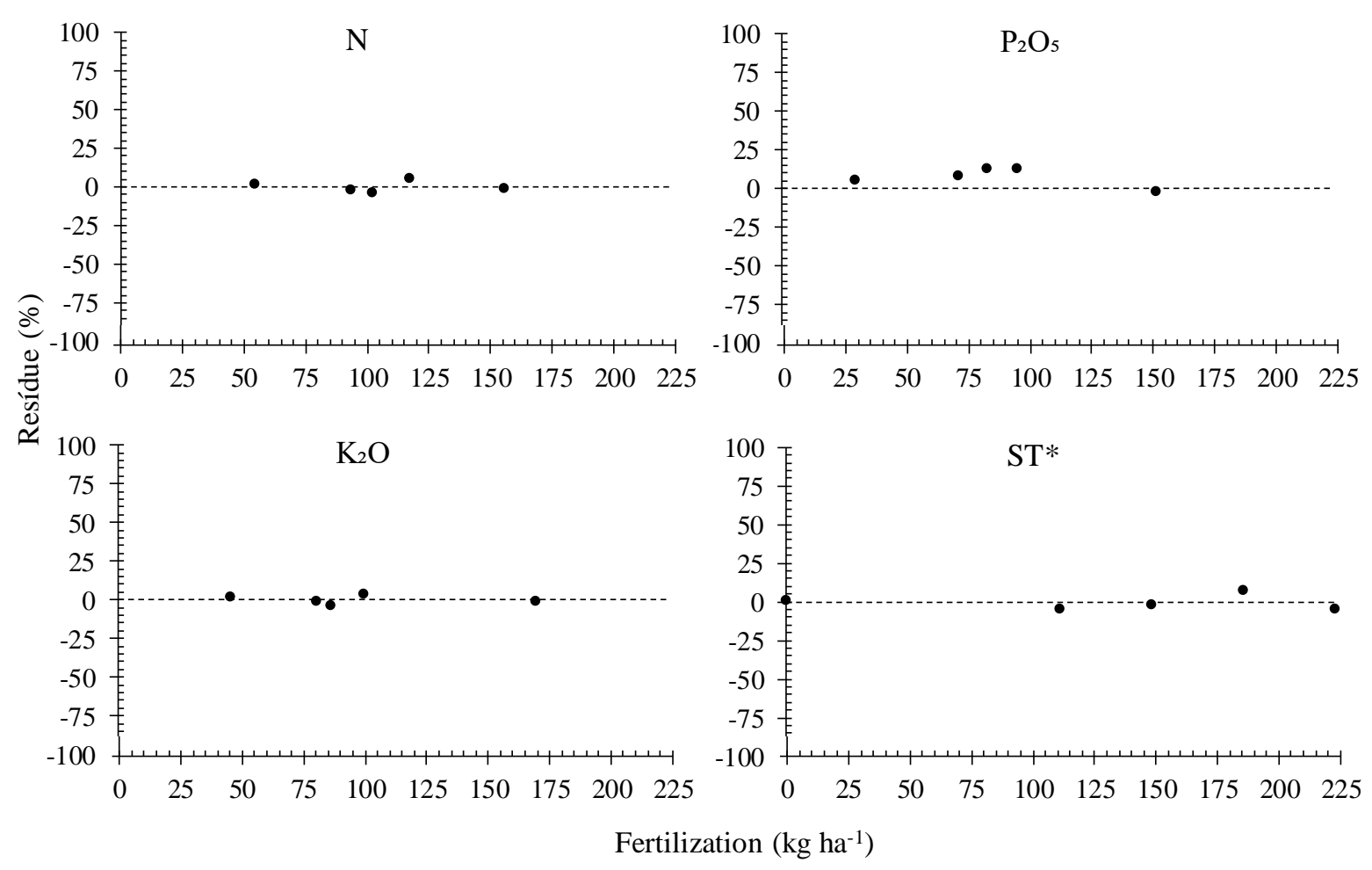

Figure 5. Percentage distribution residues as a function of quantities of mineral fertilizer

\section{Discussion}

The litterfall found in the present study was similar to that reported by Giácomo et al (2017). The authors evaluated the litter deposition response in Eucalyptus urophylla from 12 to 24 months of age in a degraded area. The amount of litterfall was 900 and $2600 \mathrm{~kg} \mathrm{ha}^{-1}$ for the treatment without fertilization (control) and with mineral fertilization as recommended by the soil analyses, respectively. Therefore, mineral fertilization in degraded areas was positive for the increase in litterfall.

The seasonal pattern of litter deposition observed is similar to that reported by Cunha et al. (1993), for a seasonal deciduous forest located in the municipality of Santa Maria, Rio Grande do Sul. These authors also observed a greater litter production in the spring, coinciding with increases in precipitation and temperature. Such behavior occurs due to both forests being located in zones of subtropical climate, without prolonged periods of cold and drought, which enhances leaf abscission in winter, before vegetation resumes growth in spring. König et al (2002) found a similar pattern, with the greatest deposition occurring in late winter (September).

Viera et al (2013), in a study of litter deposition in a stand of the hybrid Eucalyptus urophylla $\mathrm{x}$ Eucalyptus globulus, also found greater litter deposition in spring, followed by lesser deposition during autumn and winter. In addition, Corrêa et al (2013), in a stand of Eucalyptus dunnii on the Pampa biome, similar to the present study, found greater deposition in spring and summer, which differed statistically from autumn and winter. 
Assessing litter production in Eucalyptus dunnii stands in southern Brazil, Momolli et al., (2019a) and Momolli et al (2019b) report greater deposition also in the spring season. The factor that can be attributed to these results is that in the southern region of Brazil, due to the winter season with milder temperatures, there is a renewal of the foliage as soon as spring arrives, marked mainly by the increase in temperatures.

Litter deposition positively alters the environment in which the experiment is located, protecting the soil from impacts caused by exposure to winds and rain and contributing to the improvement of the chemical and physical characteristics of the soil over the years. Lopes et. al (2002) also highlight that the litter has the capacity to store water in its tissues, exercising the function of a sponge and filter, which soaks after precipitation and starts a slow release of the accumulated water to the soil, thus contributing in the process of water infiltration into the soil.

The average annual litter production for the best treatment (T5) was $1326 \mathrm{~kg} \mathrm{ha}^{-1} \mathrm{year}^{-1}$, a value much lower than that found by Carvalho (2014), who estimated the production of 8100 $\mathrm{kg} \mathrm{ha}^{-1}$ year $^{-1}$ of litter for the hybrid Eucalyptus urophylla $\mathrm{x}$ Eucalyptus grandis (four years old) in the municipality of Alegrete - RS, region of the Pampa biome. In addition, Corrêa (2013), in a study on Eucalyptus dunnii population (27 months old) in the Pampa biome observed a production of $4100 \mathrm{~kg} \mathrm{ha}^{-1}$ year $^{-1}$, with leaves representing more than $93 \%$ of the total produced.

Studying the deposition of litter in a stand of Eucalyptus dunnii at 48 months in the Pampa biome, Silva (2014) found an average annual production of $6990 \mathrm{~kg} \mathrm{ha}^{-1} \mathrm{year}^{-1}$, where $66.75 \%$ was made up of leaves. In Santa Catarina, Neves (2012) found in plantations of Eucalyptus dunnii, (24 months old) an average deposition of $7420 \mathrm{~kg} \mathrm{ha}^{-1}$ year ${ }^{-1}$ of litter, where $95 \%$ was made up of leaves. Furthermore, Cunha et al. (2005) found $3800 \mathrm{~kg} \mathrm{ha}^{-1}$ of litter production in a regrowth area of Eucalyptus grandis, in the state of Rio de Janeiro, at 18 months after the management of conduction. These higher values reinforce the idea that the maturity of the population influences the pattern of deposition. In the present study, the stand was in the juvenile stage, from 11 to 23 months of age, without canopy closure.

The annual litter production varies according to the type of ecosystem and its stage of development, besides representing the main path for the return of nutrients into the soil. The results demonstrated and discussed in this work refer to the second year of age of a Eucalyptus urophylla stand set up in a sandy environment in the Pampa biome of Rio Grande do Sul. Thus, there is need for longer sampling due to possible variations in annual litter deposition, probably related to changes in tree development from juvenile to adult stages.

The low litter deposition observed at the beginning of the assessment are related to the age of the stand. The population at the time of the study was in full development, with no canopy closure, which contributed to the quantities presented. The peak of deposition occurred after a peak of precipitation in the spring; however, subsequent peaks of precipitation did not increase deposition, showing that other factors may be influencing this behavior. Similarly, König et. al., (2002) did not find a correlation between precipitation and litter deposition. 
Litter plays an extremely important role in covering sandy soils, promoting the maintenance of humidity and protecting from the effects caused by rains and winds, in addition to increasing soil nutritional levels and microbial activity, thus increasing raw material levels. Furthermore, the litter deposited on the soil provides ideal conditions for water infiltration, considerably decreasing its runoff and thus preventing water erosion. The litter value found in this study is below those observed in most plantations, including in stands of the same age but located under different environmental conditions.

Our study showed a good adjustment of the litter production coefficient by the amount of fertilizer applied. The increase in 195, 216, 276 and $442 \%$ of mineral fertilizer in treatments 2, 3,4 and 5, represented litterfall gains of 87, 104, 108 and 156\% respectively.

Assessing the mineral fertilization response in Pinus radiata at the age of 12 in southwest Australia, Theodorou and Bowen (1990) found a litter quantity of $2346 \mathrm{~kg} \mathrm{ha}^{-1}$ in the treatment without fertilization and $3770 \mathrm{~kg} \mathrm{ha}^{-1}$ in the treatment with fertilization. These values represent a $61 \%$ increase for the fertilization treatment. The site was fertilized over a period of three years with the quantities of 806: 178: $366 \mathrm{~kg} \mathrm{ha}^{-1}$ for N: P: K respectively.

Assessing litterfall in a stand under different fertilization treatments in Eucalyptus urophylla S.T. Blake and E. grandis Hill ex Maiden on sandy soil from 12 to 24 months of age, Silva et al., (2013) found an annual deposition that ranged from 3204 to $6633 \mathrm{~kg} \mathrm{ha}^{-1}$. This significant increase was $107 \%$. The researchers concluded that the eucalypts responded positively to increasing doses of the fertilizers and that fertilization increased the nutrient cycling through the litterfall.

These results are important because litterfall represents the main component for the biogeochemical cycle in young Eucalyptus stands (Caldeira et al., 1999; Laclau et al., 2010). This factor is even more important when the soils are sandy, degraded or in a process of degradation and of low natural fertility, as is the case of the present study.

\section{Conclusion}

The litterfall presented a seasonal behavior and the spring, marked by the increase in temperatures, was responsible for the greater litter deposition. The increase in litter production is associated with the amount of fertilizers. Therefore, the management of fertilization, with greater amounts of nutrients, increases the production of litter and consequently accelerates the process of nutrient cycling.

In degraded areas, application of faster-release mineral fertilizers indicate higher litterfall. Depending on the amount and type of fertilization and nutrient release, the increase in litterfall was $158 \%$ in 1 year. Higher litterfall was observed with increasing precipitation.

\section{References}

Alvares, C. A., Stape, J. L., Sentelhas, P. C., Gonçalves, J. L. M., \& Sparovek, G (2013). Köppen.s climate classification map for Brazil. Meteorologische Zeitschrift, https://doi.org/10.1127/0941-2948/2013/0507 
Barros, N. F., \& Comeford, N. B. (2002). Sustentabilidade da produção de florestas plantadas na região tropical. In ALVAREZ, V. V. H. et al. Eds. Tópicos em ciência do solo. Viçosa, Sociedade Brasileira de Ciência do Solo, Folha de Viçosa.

Barros, N. F., \& Novais, R. F. (1995). Eucalypt nutrition and fertilizer regimes in Brazil. In: Atti-Will, P. M. \& Adams, M. A. (Eds.). Nutrition of the Eucalypt. Collingwood: Csiro. 335-356.

Caldeira, M. V. W., Schumacher, M. V., Pereira, J. C., Della Flora, J. B., \& Santos, E. M. (1999). Concentração e redistribuição de nutrientes nas folhas no folhedo em um povoamento de Acacia mearnsii de Wild. no Rio Grande do Sul. Cienc. Florest., 9, 19-24. https://doi.org/10.5902/19805098361

Carvalho, R. R. (2014). Biomassa e nutrientes em um povoamento de Eucalyptus urograndis estabelecido em solo sujeito a arenização no sul do Brasil. 2014. 80 p. Dissertação (Mestrado em Engenharia Florestal) - Universidade Federal de Santa Maria, Santa Maria.

Corrêa, R. S., Schumacher, M. V., \& Momolli, D. R. (2013). Deposição de serapilheira e macronutrientes em povoamento de Eucalyptus dunnii Maiden sobre pastagem natural degradada no Bioma Pampa. Scientia Forestalis, 41(97), 065-074.

Cunha, G. C. et al. (1993). Dinâmica nutricional em floresta estacional decidual com ênfase aos minerais provenientes da deposição da serapilheira. Ciência Florestal, 3(1), 35-64. https://doi.org/10.5902/19805098284

Cunha, G. M. et al. (2005). Ciclagem de nutrientes em Eucalyptus grandis W. Hill ex Maiden no norte fluminense. Revista Árvore. Viçosa, 29, 253-363. https://doi.org/10.1590/S0100-67622005000300002

FAO, (2020). Global Forest Resources Assessment. [s.1.]: Available in: <http://www.fao.org/documents/card/en/c/ca8753en>.

Fonseca, S. M. et al. (2010). Manual Prático de Melhoramento Genético do Eucalipto. Viçosa: Ed. UFV, 200 p.

Giácomo, R. G. et al (2017). Litterfall and Nutrient Input in a Degraded Area. Floresta e Ambiente, 24(0). https://doi.org/10.1590/2179-8087.002816

Gonçalves, J. L. M. et al. (2004). An evaluation of minimum and intensive soil preparation regarding fertility and tree nutrition. In: Gonçalves J.L.M.; Benedetti, V. (Eds.) Forest nutrition and fertilization. Piracicaba: IPEF.

IBÁ - Indústria Brasileira de Árvores (2020). Statistical yearbook 2020, base year 2019. Available in: <https://iba.org/datafiles/publicacoes/relatorios/relatorio-iba-2020.pdf>.

IBM Corp. (2011). Released. IBM SPSS Statistics for Windows, Version 20.0. Armonk, NY: IBM Corp.

IFCRS. RIO GRANDE DO SUL. Governo do Estado. Secretaria Estadual do Meio Ambiente, Inventário Florestal Contínuo do RS, 2002. Disponível em: <http://coralx.ufsm.br/ifcrs> 
König, F. G., Schumacher, M. V., Brun, E. J., \& Seling, I. (2002). Avaliação da sazonalidade da produção de serapilheira numa floresta estacional decidual no município de Santa Maria RS. Revista Árvore, Viçosa-MG, 26(4), 429-435.

https://doi.org/10.1590/S0100-67622002000400005

Laclau, J. P., Ranger, J., Gonçalves, J. L. M., Maquere, V., Krusche, A. V., M’bou, A. T., ... Deleporte, P. (2010). Biogeochemical cycles of nutrients in tropical Eucalyptus plantations Main features shown by intensive monitoring in Congo and Brazil. For. Ecol. Manage. 259, 1771-1785. https://doi.org/10.1016/j.foreco.2009.06.010

Lopes, M. I. M., Domingos, M., \& Vuono, Y. S. (2002). Ciclagem de nutrientes minerais. In: Sylvestre, L. S.; Rosa, M. M. T. Manual metodológico para estudos botânicos na Mata Atlântica. Seropédica: EDUR, p. 72-103.

Momolli, D. R., Schumacher, M. V., Ludvichak, A. A., Santos, K. F., Souza, H. P., \& Guimarães, C. C. (2019a). Nutrient cycling in Eucalyptus dunnii: micronutrients in the litterfall. Floresta, 49(4), 641-650. https://doi.org/10.5380/rf.v49i4.56727

Momolli, D. R., Schumacher, M. V., Viera, M., Ludvichak, A. A., Guimarães, C. C., \& Souza, H. P. (2019b). Litterfall and Nutrient Return in Eucalyptus dunnii Maiden in the Pampa Biome, Brazil. J. Agric. Sci., 11, 362. https://doi.org/10.5539/jas.v11n5p362

Neves, C. U. (2012). Ciclagem de nutrientes em plantios de Eucalyptus dunnii com idade de 1, 2 e 3 anos no Planalto Sul Catarinense. 2012. 94 p. Dissertação (Mestrado em Manejo do Solo) - Universidade do Estado de Santa Catarina, Lages.

O'connell, A. M., \& Mendham, D. S. (2004). Impact of N and P fertilizer application on nutrient cycling in jarrah (Eucalyptus marginata) forests of south western Australia. Biol. Fertil. Soils, 40(2), 136-143. https://doi.org/10.1007/s00374-004-0753-3

Rovedder, A. P. M., \& Eltz, F. L. F. (2008). Desenvolvimento do Pinus elliottii e do Eucalyptus tereticornis consorciado com plantas de cobertura, em solos degradados por arenização. Ciência Rural, Santa Maria, 38(1), 84-89.

https://doi.org/10.1590/S0103-84782008000100014

SBCS-CQFS - Sociedade Brasileira de Ciência do Solo-Comissão de Química e Fertilidade do Solo - RS/SC. Manual de calagem e adubação para os Estados do Rio Grande do Sul e de Santa Catarina. 11ª ed. Solo - Núcleo Regional Sul. Porto Alegre. 2016, 376 p.

Silva, J. C. M. (2014). Ciclagem biogeoquímica de nutrientes em Eucalyptus dunnii Maiden em uma microbacia hidrográfica experimental do bioma Pampa. 111 p. Tese (Doutorado e Engenharia Florestal) - Universidade Federal de Santa Maria, Santa Maria.

Silva, P. H. M., Poggiani, F., Libardi, P. L., \& Gonçalves, A. N. (2013). Fertilizer management of eucalypt plantations on sandy soil in Brazil: Initial growth and nutrient cycling. Forest Ecology and Management, 301,

67-78. https://doi.org/10.1016/j.foreco.2012.10.033

Suertegaray, D. M. (1995). O Rio Grande do Sul descobre os seus desertos. Ciência \& 
Ambiente, 11, 33-52.

Theodorou, C., \& Bowen, G. D. (1990). Effects of fertilizer on litterfall and N and P release from decomposing litter in a Pinus radiata plantation. Forest Ecology and Management, 32(2-4), 87-102. https://doi.org/10.1016/0378-1127(90)90163-6

Viera, M., Schumacher, M. V., \& Caldeira, M. V. W. (2013). Dinâmica de Decomposição e Nutrientes em Plantio de Eucalyptus urophylla x Eucalyptus globulus no sul do Brasil. Florest a e Ambiente, 20(3), 351-360. https://doi.org/10.4322/floram.2013.021

\section{Copyright Disclaimer}

Copyright for this article is retained by the author(s), with first publication rights granted to the journal.

This is an open-access article distributed under the terms and conditions of the Creative Commons Attribution license (http://creativecommons.org/licenses/by/4.0/). 